Ministry of Education

Deputy Minister

Mowat Block

Queen's Park

Toronto ON M7A 1L2
Ministère de l'Éducation

Sous-ministre

Édifice Mowat

Queen's Park

Toronto ON M7A 1L2

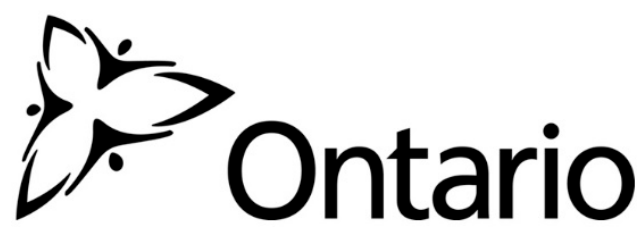

2019:B08
Date:

Memorandum to:

From:

Subject
March 15, 2019

Directors of Education

Secretary/Treasurers of School Authorities

Nancy Naylor

Deputy Minister

New Vision for Education

Today, the government released its new vision for education, Education that Works for You. I am writing to provide you with an overview of the vision and its key elements.

\title{
MODERNIZING CLASSROOMS IN ONTARIO
}

As you know, the ministry has been consulting with education partners to seek feedback on class size considerations.

The ministry held in-person meetings in January 2019 with the teachers' federations, trustees' associations and education worker unions to gather feedback. School boards, principals/vice-principals' associations and other education sector partners were also invited to provide written feedback between January 23 and February 22, 2019.

The ministry received almost 500 written submissions from the public, including parents, teachers and early childhood educators. While the prior phases of the consultation are now complete, the ministry has invited partners to continue this important dialogue through the next consultation.

This consultation will ensure partners can provide feedback on the government's proposed plans.

The consultation period will continue until May 31, 2019. To provide families, staff, and school boards with certainty on the government's direction, the government will move 
forward on next steps, including any required legislation, in time for the next school year.

\section{Class Size}

The government is committed to supporting students and families as education funding is modernized in a responsible manner.

The government looks forward to the continued consultation with education partners to help shape the government's plans. The proposed changes for 2019-20 are as follows:

- Kindergarten - There are no proposed changes to either the caps or the average class size requirements. Funded average class sizes would remain at the current level of 25.57 and there would be a minimal reduction to funded Registered Early Childhood Educators (RECEs) from 1.14 to 1.0. This will not change the educator to student ratio. The ministry will also introduce new funding to assist with RECE supply costs.

- Primary (grades 1 to 3) - hard caps remain in place. There are no proposed changes to either the caps or the average class size requirements.

- Intermediate (grades 4 to 8 ) - all school boards would be required to maintain a board wide average class size of 24.5 or less, while the funded average class size would be minimally increased from 23.84 to 24.5 . This would standardize funding and class sizes across the province as historically, there has been variability for these grades.

- Secondary (grades 9 to12) - average class size requirements adjusted from 22 to 28 students to align secondary class sizes more closely with other jurisdictions across Canada. School boards would be required to maintain a board wide average class size of 28 or less and the funded average class size would be increased to 28 to support this change. In addition, school operations funding would be adjusted accordingly.

The consultation period will continue until May 31, 2019. To provide families, staff, and school boards with certainty on the government's direction, the government will move forward on next steps, including any required legislation, in time for the next school year.

\section{E-learning}

The government is committed to modernizing education and supporting students and families in innovative ways that enhance their success. A link to e-learning courses can be found here: www.edu.gov.on.ca/elearning/courses.html 
Starting in 2020-21, the government will centralize the delivery of all e-learning courses to allow students greater access to programming and educational opportunities, no matter where they live in Ontario. The average class size would be adjusted to an average of 35 .

Secondary students will take a minimum of four e-learning credits out of the 30 credits needed to fulfill the requirements for achieving an Ontario Secondary School Diploma. That is equivalent to one credit per year, with exemptions for some students on an individualized basis. These changes to graduation requirements will be phased in, starting in 2020-21.

With these additional modernizations, the secondary programming amount in the Pupil Foundation Grant will no longer be provided, effective September 2019.

\section{Attrition Protection}

The government is committed to achieving greater financial sustainability in the education system without involuntary front line lay-offs. The proposed changes to class sizes may have implications for teacher staffing in Ontario school boards.

The ministry plans to introduce a new funding allocation that will top-up school boards where the change in funded teachers exceeds the actual attrition and other voluntary leaves. With this support in place, it is expected that boards will not be required to initiate lay-offs of teachers associated with the proposed changes in class sizes. The ministry will provide attrition protection for up to four years, allowing boards to phase in the proposed class sizes.

The attrition protection would apply to the proposed class size policy changes, including e-learning. Regarding declining enrolment, school boards should follow their normal processes, but should account for teacher retirements, voluntary departures, and their declining enrolment allocation to avoid lay-offs. Some Ontario school boards may be in this position, as in previous years.

School boards are advised to exercise restraint in hiring to replace retiring teachers or teachers leaving voluntarily.

\section{Hiring Practices}

Ontario Regulation 274/12, under the Education Act, established mandatory processes that all English-language school boards must follow when hiring long-term occasional and permanent teachers.

However, since its implementation in 2012, stakeholders, including parents, principals, directors of education and teachers, have raised concerns about the regulation - such as increased principal workload and classroom teacher turnover. 
The ministry held in-person meetings in January 2019 with the teachers' federations, trustees' associations and education worker unions to gather feedback. Stakeholders were also invited to provide written feedback. The ministry received 80 written submissions from stakeholders and the public. The majority of submissions were supportive of increased teacher mobility. While the prior phases of the consultation are now complete, the ministry has invited partners to continue this important dialogue through the next consultation.

To address these concerns, the government's objective is to work with its education partners to improve teacher mobility while increasing transparency, fairness, consistency, and accountability in teacher hiring across all school boards. The government's goal is to ensure that students are supported by qualified teachers and that principals are able to hire teachers based on merit who are a good fit for the role.

\section{Grants for Student Needs Funding}

There will be limited changes made to the GSN in the following areas:

Local Priorities Fund

The Local Priorities Fund (LPF), first established in 2017-18 during the last round of collective bargaining, expires on August 31, 2019. Whether the funding for staffing is extended is an issue subject to the upcoming central collective bargaining process. The increases related to salary will continue as well as the principals' and vice-principals' funding which is not set to expire until August 31, 2020.

Cost Adjustment Allocation

Historically, the base amount of the Cost Adjustment Allocation was providing supplemental funding for education worker benchmarks. As school boards have flexibility through other grants in the GSN to address their staffing needs, this amount has been discontinued for the 2019-20 school year.

\section{Human Resource Transition Supplement}

The Human Resource Transition Supplement was intended to be a temporary support to assist school boards with the negotiated 2017-19 agreements. This temporary transitional supplement amount has been discontinued for the 2019-20 school year.

\section{Classroom Loading Factors}

To reflect the proposed secondary class size changes, the factors that determine the amount of funding for the operation of school facilities will be adjusted.

\section{Utilities Funding}

As in previous years, funding will be increased to support increased costs associated with the heating and lighting of school facilities. 
Student Transportation Funding

As in previous years, funding will be increased to support higher costs associated with student transportation. Also, additional funding supports are planned for school boards that run efficient transportation operations but for which the costs of student transportation exceed the funding provided for that purpose.

Finally, the ministry intends to undertake a review of the student transportation funding formula in order to achieve a more efficient and accountable student transportation system in Ontario.

Continued Implementation of 2017-19 Central Labour Agreements

As in previous years, funding will be increased to reflect the salary adjustments related to the 2017-19 Central Labour Agreements.

\section{Timing of Annual Grant Announcement}

More details, including board-by-board allocations, will be available as part of the annual funding formula announcement planned for later this spring. The summarized information in Appendix $A$ is intended to guide school boards about key policy changes to assist in upcoming planning and budgeting cycles prior to the funding announcement planned to be released prior to the end of April.

\section{Technology (Broadband)}

Broadband is foundational for supporting modernized, digital learning in the classroom.

Ontario students and educators will have access to reliable, fast, secure and affordable internet services at school at a speed of one megabit per-second per-student in all regions of the province. The project will be completed by 2021-22 and will include all boards, schools and students.

To complete this project, the needs of each school will be individually assessed, and then individual technical solutions will be implemented. Broadband expansion is already underway at a majority of northern and rural schools. Thirty-two per cent of northern schools have completed their upgrades, and 35 per cent of rural schools have been completed.

\section{Cellphones}

During the government's consultation on education reform in fall 2018, parents, students and teachers expressed the view that cell phones have the potential to be useful learning tools - but too often they are a distraction from learning and have a negative impact on the classroom experience.

In response to this feedback, the Provincial Code of Conduct will be updated to prohibit cell phone use in schools during instructional time as of September 2019. 
Use of personal mobile devices (e.g. cell phones) during instructional time will be permitted under the following circumstances:

- For educational purposes, as directed by the educator

- For health and medical purposes

- To support special education needs.

Boards and stakeholders will be consulted to ensure students and parents are clear on the new guidelines, including exceptions.

\section{Education Quality and Accountability Office}

Student achievement is one of the keys to success in a competitive global economy. The Education Quality and Accountability Office (EQAO) can provide vital data and research to reinvigorate education in Ontario, help improve student learning at the provincial, board and school level, and help identify achievement gaps to promote greater equity in the publicly funded education system.

Therefore, the government is committed to working with EQAO to modernize the agency and its processes while using data to build better assessment and evaluation models that have a greater focus on equity.

\section{MODERNIZING LEARNING IN ONTARIO}

The government's new vision for education will modernize learning throughout the province's education system.

Following the feedback from the consultation on education held last fall, the province will be moving forward with changes in the following areas:

\section{Math}

The government has announced a new four-year math strategy to ensure students have a strong understanding of math fundamentals and how to apply them. This strategy will:

- Improve student performance in math

- Help students solve everyday math problems

- Increase students' employability into the jobs of tomorrow.

The strategy will feature a new math curriculum for all students in all grades phased in over four years. The curriculum will emphasize basic concepts and skills contributing to students' future success and be accompanied by parent and teacher resources. The first elements of the new curriculum will be available in September 2019.

In addition to an improved curriculum, online resources will be available to support student learning. The government has also introduced legislation that will require new 
teachers to pass a math content knowledge test before they enter the classroom in a professional capacity. If passed, this legislation will ensure teachers are confident and capable in teaching math and by the spring of 2020 , will be required to pass the test in order to be certified by the Ontario College of Teachers.

For teachers already in the system, the government will provide funding to support additional qualification courses in math.

\section{Science, Technology, Engineering and Math}

The government is committed to preparing Ontario students for success by equipping them with the skills they need in Science, Technology, Engineering and Math (STEM).

The new STEM Education Strategy will enable Ontario to become a global leader in STEM learning. By partnering with educators, students, parents, post-secondary institutions as well as industry leaders, the government will create new and enriched learning experiences in STEM.

An immediate step will be a revised mandatory Career Studies Grade 10 course. This revised course will explore high-growth industries, including STEM, which will reflect new mandatory learning for students. This course will be released in late May for implementation in September 2019.

The strategy will also include revised Business Studies and Computer Studies curricula focused on developing job skills such as entrepreneurial skills, computational thinking and coding. In 2019-20, the ministry will begin research and benchmarking against other jurisdictions as a foundation for revisions to these curricula.

\section{Skilled Trades}

Ontario students have experienced significant success through the Specialist High Skills Major and Dual Credit programs, which have provided opportunities for students to experience skilled trades and apprenticeships. The Ministry of Education will work closely with the Ministry of Training, Colleges and Universities to increase student and parent exposure to skilled trades, technology and apprenticeship training, and focus on promoting this high-demand career pathway.

We want to ensure that students are exposed to:

- A broad range of opportunities that will offer exposure to skilled trades and technology careers, and that they are exposed to these opportunities starting in elementary school.

- Experiential, hands-on learning through community partnerships and co-op placements. 


\section{Financial Literacy}

Financial literacy learning is essential to student success to build a well-educated responsible workforce and prepare Ontarians for a more prosperous future.

Financial literacy will be a major component of the mandatory learning in the revised Grade 10 Career Studies course which will be released in late May for implementation in September 2019.

It will also be an area of focus in the revised math curriculum being phased in for all grades.

\section{Indigenous Education}

A revised First Nations, Métis, and Inuit Studies curriculum for Grades 9-12 will be released in late May for implementation in September 2019. The curriculum was developed in collaboration with Indigenous partners to increase learning about Indigenous perspectives, cultures, contributions and histories.

Building on this, the government will continue to work with Indigenous partners to develop an approach for more curriculum revisions across subjects, grades and courses, to strengthen Indigenous content and learning.

\section{Health and Physical Education (HPE)}

Following feedback from the largest provincial consultation on education, the government heard the need for an HPE curriculum that is age-appropriate and relevant. The revised elementary HPE curriculum will be released in late May for September 2019 implementation. From now until the end of the 2018-2019 school year, educators will continue using the 2018 curriculum, their professional judgement, and ageappropriate resources to teach the students in their classroom.

To ensure parents are respected, the ministry will provide an opt-out policy similar to other jurisdictions. The ministry will also be introducing online modules for parents who may want to introduce topics at home whenever their child is ready. Both of these options will be available for the 2019-20 school year.

\section{Digital Curriculum}

A new digital platform will be phased in to modernize access to Ontario's curriculum. This new digital space will help educators, parents and students access curriculum and learning resources in a user- and mobile-friendly manner and will become increasingly interactive over time. The first phase of the new platform will be launched in September 2019 and will grow steadily with more content and features, in line with user needs and feedback. 
The initiatives set out in this memorandum would be supported by proposed changes to the GSN regulation, and other legislation, where necessary. The ministry will provide further information about any legislative changes as they are brought forward.

We want to thank school boards for their ongoing dedication to providing programs and supports to all students. We look forward to continued consultation with education partners and collaboration on the government's priorities for education.

Original signed by

Nancy Naylor

Deputy Minister 


\section{Appendix A: Planning Assumptions}

To support board planning, the table below summarizes the changes that boards can plan for with respect to funding subject to consultations, negotiations and potential legislative changes.

The ministry anticipates the annual funding formula to be released in late April.

\begin{tabular}{|c|c|}
\hline Description & Funding Changes * \\
\hline Kindergarten & $\begin{array}{l}\text { - Funded Early Childhood Educators (ECE) } \\
\text { classroom staffing ratio change from 1.14 FTE to } \\
\text { 1.0 FTE }\end{array}$ \\
\hline Grades 1 to 3 & - $\quad$ Funded average class sizes remains at 19.8 \\
\hline Grades 4 to 8 & $\begin{array}{l}\text { - Funded average class size adjusted from } 23.84 \\
\text { to } 24.5\end{array}$ \\
\hline Grades 9 to 12 & $\begin{array}{ll}\text { - Funded average class size adjusted from } 22 \text { to } \\
28\end{array}$ \\
\hline E-learning & $\begin{array}{l}\text { - Funded average class size adjusted to } 35 \\
\text { starting in 2020-21 school year }\end{array}$ \\
\hline $\begin{array}{l}\text { Secondary Programming amount in } \\
\text { Pupil Foundation Grant }\end{array}$ & - $\quad$ Funding to end August 31, 2019 \\
\hline Local Priorities Fund & - $\quad$ Funding to end August 31, 2019 \\
\hline Cost Adjustment Allocation & - $\quad$ Base amount to end August 31, 2019 \\
\hline $\begin{array}{l}\text { Human Resource Transition } \\
\text { Supplement }\end{array}$ & - $\quad$ Funding to end August 31, 2019 \\
\hline $\begin{array}{l}\text { Classroom Loading Factors in } \\
\text { School Facility Operations and } \\
\text { Renewal Grant }\end{array}$ & $\begin{array}{l}\text { - Five-year phase-in of a new Supplementary Area } \\
\text { Factor for school facility operations to reflect } \\
\text { proposed secondary class size changes. }\end{array}$ \\
\hline $\begin{array}{l}\text { School Facility Operations and } \\
\text { Renewal Grant (Utilities) }\end{array}$ & $\begin{array}{l}\text { A } 2 \text { per cent update to the non-staff portion of the } \\
\text { operating cost benchmark under the School } \\
\text { Facility Operations and Renewal Grant (School } \\
\text { Operations Allocation) to assist in managing } \\
\text { increases in commodity prices (electricity, natural } \\
\text { gas, facility insurance, and other costs). }\end{array}$ \\
\hline Student Transportation & $\begin{array}{l}\text { - A } 4 \text { per cent cost update adjustment, net of } \\
\text { previous years' transportation surplus, if any. } \\
\text { - Funding for school boards running transportation } \\
\text { deficits and have demonstrated efficient consortia } \\
\text { operations. }\end{array}$ \\
\hline $\begin{array}{l}\text { Attrition Protection for Teachers for } \\
\text { Class Size Changes (including e- } \\
\text { Learning) }\end{array}$ & $\begin{array}{l}\text { - Funded class sizes and staffing parameters in } \\
\text { the Pupil Foundation Grant as well as other } \\
\text { related components in the GSN would be } \\
\text { adjusted to reflect the above proposed changes } \\
\text { to class sizes. } \\
\text { If the reduction in the funded teacher FTE } \\
\text { amount after these changes exceeds attrition, a } \\
\text { top-up in funding will be provided so that the } \\
\text { funded change does not exceed attrition. }\end{array}$ \\
\hline
\end{tabular}




\begin{tabular}{|l|c|}
\hline Description & Funding Changes * \\
\hline & $\begin{array}{l}\text { Attrition is the sum of actual retirements and } \\
\text { other voluntary leaves. This calculation will be } \\
\text { done for each panel separately. Declining }\end{array}$ \\
& $\begin{array}{l}\text { enrolment is not covered by attrition protection. } \\
\text { With this support in place, boards can avoid } \\
\text { teacher lay-offs. }\end{array}$ \\
\hline Salary Benchmarks & $\begin{array}{l}\text { To be adjusted by 1 per cent to support } \\
\text { previously negotiated central collective } \\
\text { agreements, as well as the amount for the } \\
\text { provincial terms and conditions agreement for } \\
\text { Principals and Vice-Principals. }\end{array}$ \\
\hline
\end{tabular}

* Proposed funding changes are subject to consultations, negotiations and potential legislative changes. 